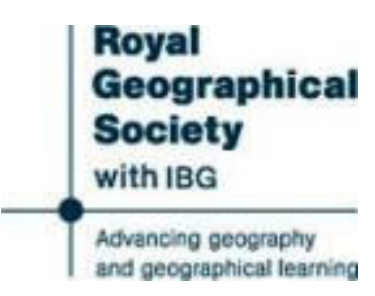

Further Exploration in the Hunza-Nagar and the Hispar Glacier

Author(s): Fanny Bullock Workman

Source: The Geographical Journal, Vol. 32, No. 5 (Nov., 1908), pp. 495-496

Published by: The Royal Geographical Society (with the Institute of British Geographers)

Stable URL: http://www.jstor.org/stable/1777169

Accessed: 18-03-2015 16:47 UTC

Your use of the JSTOR archive indicates your acceptance of the Terms \& Conditions of Use, available at http://www.jstor.org/page/info/about/policies/terms.jsp

JSTOR is a not-for-profit service that helps scholars, researchers, and students discover, use, and build upon a wide range of content in a trusted digital archive. We use information technology and tools to increase productivity and facilitate new forms of scholarship. For more information about JSTOR, please contact support@jstor.org.

The Royal Geographical Society (with the Institute of British Geographers) is collaborating with JSTOR to digitize, preserve and extend access to The Geographical Journal. 


\title{
FURTHER EXPLORATION IN THE HUNZA-NAGAR AND THE HISPAR GLACIER.*
}

\author{
By Mrs. FANNY BULLOCK WORKMAN.
}

Dr. Hunter Workman and myself, accompanied by Dr. C. Calciati and Dr. M. Koncza-former pupils of Prof. Jean Brunhes and graduates of the University of Fribourg, Switzerland-as topographers, Cyprian Savoye, guide of Courmayeur, and three Italian porters, have finished a very interesting visit to Hunzar-Nagar and the Hispar glacier. The object of the expedition, in particular, was to make a detailed survey of all the branches of this glacier, and explore them to their sources, this not having been done by Sir Martin Conway in his rapid ascent of the Hispar in 1892. Being favoured generally with very fine weather, this plan was to a large extent successfully accomplished.

Careful note was taken of Mr. H. Hayden's stations, on behalf of the Geological Survey, at the tongues of the Hassanabad, Tengutsa, and Hispar glaciers, changes noted and all observation-points including a number in addition to those of Mr. Hayden marked in red. Special attention was given to investigation of the Nuskik La as a practicable pass for a caravan to the Basha valley. Neither of the routes over it, drawn on Sir Martin Conway's map, are at present feasible for loaded coolies. The danger from avalanches is imminent at all hours of the day. Huge séracs, and above them overhanging cornices, give way constantly, crashing down upon the route to be taken. Starting very early with guide and porters only, we visited the col and climbed a snow-summit rising 1500 feet or more above it to the east. On reaching our base-camp afterwards, the guide remarked he was glad that that climb was over, and that he should not care to incur the risk a second time. Doubtless the snow conditions have greatly changed on the Hispar side in the last fifteen Jears. The ascent from the south, the Baltistan side, to the col is perfectly simple, as we saw from above the pass.

Much of topographical and glaciological interest was found on the ascents of the 12 and 15 mile long northern branches, the Gutun, Kanibasar, and the highest, most northern icy branch, which ascends on the Nagar side of the Hispar pass to a col of about 19,000 feet overlooking a large enclosed glacier. The topograpby of these was quite different from that shown on existing maps. We made a base-camp at a height of 16,000 feet for ten days on the final mountain-flank of right bank, at the base of the last sérac leading to the Hispar or Zong La. From here, ascending north-east over ice-falls, and for some miles over a wide snow plateau, and finally up a sheer 1000 -feet snow-slant, we brought

* Dated "Skardu, September 10, 1908." 
fifteen coolies and small camp to a snow-flat under a very sharp triangular snow-pyramid which crowns the watershed between the Hispar and Biafo glaciers. This camp was at over 19,000 feet. Our heights have not yet been finally calculated.

The next day, with guide and two porters, I ascended this peak, while Dr. Workman with a porter climbed a somewhat lower summit for photographic and observation purposes. Tho east arête of the higher peak, the Biafo watershed side, while less steep was so fluted with cornices that we dared not attempt it, so we climbed by the much sharper south one facing the Hispar, which was a risky, very abrupt knife-edge slant of over 2000 feet. By judicious step cutting we reached the tiny corniced top in safety. The view from this mountain is perhaps the most comprehensive and beautiful $I$ have seen in the Himalayas. A page would not suffice to describe it, but in this note I will only say, that from its position high above Snow lake this summit, overlooking as it does the full sweeps of the Hispar and Biafo glaciers and the great peaks to the source of the Baltoro, may be said to include in its vista of a 60-mile range east and west a panorama of superlative grandeur of one of the most magnificent mountain regions of the world. We did not go to the Hispar glacier to indulge in high climbing, for the mountains are not suitable for such exploits, but I am glad I did not resist the sudden impulse to climb this peak, for I should have missed a rare hour of Himalayan mountain glory, and a view of topographical and geographical importance. The height of the mountain will probably work out at between 21,000 and 22,000 feet.

On August 16, with a caravan of Nagar coolies we crossed the Hispar pass to the Biafo glacier. The large glacier running from Snow lake south-east behind the B 15 range was investigated, and a passage looked for to the north of that range, which we hoped might lead to a possible route to the Punmah glacier, but the only available pass was found quite beyond the mountaineering capacity of loaded coolies. We descended the Biafo glacier, reaching Askole on August 25. This was our second visit to this glacier, the first having been made in 1899.

\section{THE PORT OF MANCHESTER: THE INFLUENCE OF A GREAT CANAL.}

By JOHN M'FARLANE, Lecturer in Geography at the University of Manchester.

The present seems a suitable moment for reviewing the development of the port of Manchester, and for attempting to estimate the place which it holds as an importing and exporting centre. There is no doubt that the sanguine expectations of those who promoted the construction of the canal have not as yet been fulfilled. On the other hand, progress has been steady and continuous, and we would make our dominant note this-that the port of Manchester, because of its geographical 